\title{
PERBANDINGAN POTENSI TELBIVUDIN DAN TENOFOVIR DALAM MENURUNKAN SKOR ASPARTATE TRANSAMINASE TO PLATELET RATIO INDEX (APRI) PADA PASIEN HEPATITIS B
}

\author{
Bogi Pratomo Wibowo* ${ }^{\star}$, Edy Susanto*, Supriono*, Syifa Mustika*
}

Abstrak

Telbivudin dan tenofovir merupakan analog nukleosida untuk terapi hepatitis B dengan efektivitas tinggi meskipun telbivudin memiliki resistensi yang lebih tinggi daripada tenofovir. Telbivudin memiliki resistensi 2,3-5\% pasien pada terapi tahun pertama dan $21,6 \%$ pasien pada terapi tahun kedua, sedangkan tenofovir dapat digunakan selama 3 tahun tanpa memunculkan resistensi. Hal ini menyebabkan tenofovir direkomendasikan sebagai terapi lini pertama oleh beberapa panduan. Namun,sampai saat ini belum ada obat pengganti apabila terjadi resistensi tenofovir. Tujuan pengobatan hepatitis B disamping menekan HBV DNA juga memperbaiki histologi jaringan hati. Maka, perlu dilakukan penelitian untuk membandingkan potensi telbivudin dan tenofovir sebagai pilihan terapi hepatitis B kronis dengan melihat penurunan HBV DNA dan skor aspartate transaminasi to platelet ratio index (APRI). Penelitian menggunakan rancangan cohort retrospective dengan pengambilan sampel secara cross-sectional. Data rekam medik dari pasien dengan terapi telbivudin dan tenofovir meliputi parameter skor APRI, yaitu kadar AST dan jumlah platelet, serta HBV DNA bulan 0 dan bulan 12. Data skor APRI dibandingkan menggunakan uji t independen dan dependen dengan nilai $P<0,05$. Dari 145 pasien, sebanyak 103 pasien mendapat terapi telbivudin dan 42 pasien diterapi dengan tenofovir. Rerata penurunan skor APRI pada kelompok telbivudin adalah $1,17 \pm 0,17$ sedangkan pada kelompok tenofovir $0,75 \pm 0,42$. Pada kedua kelompok terjadi penurunan skor APRI sebelum dan sesudah terapi yang signifikan $(p=0,00)$. Namun, tidak didapatkan perbedaan yang bermakna antara kedua kelompok $(p=0,28)$. Dapat disimpulkan, tidak terdapat perbedaan yang signifikan dalam potensi terapi antivirus antara telbivudin dan tenofovir dalam menurunkan skor APRI pasien hepatitis $B$ kronis.

Kata kunci: hepatitis B, skor APRI, telbivudin, tenofovir.

\section{POTENTIALS COMPARISON OF TELBIVUDINE AND TENOFOVIR IN DECREASING THE ASPARTATE TRANSAMINASE TO PLATELET RATIO INDEX (APRI) SCORE IN CHRONIC HEPATITIS B PATIENTS}

\begin{abstract}
Telbivudine and tenofovir are nucleoside analogs for chronic hepatitis B with high effectiveness although telbivudine has a higher resistance than tenofovir. Telbivudine has resistance of up to $5 \%$ of patients in the first year of therapy and $22 \%$ of patients in the second year of therapy, while tenofovir can be used for 3 years without eliciting resistance. This causes tenofovir to be the first line of antiviral for hepatitis $B$. The concern is that if there is tenofovir resistance, there is no substitute drug that can be used. The purpose of hepatitis B treatment besides suppressing HBV DNA is also to improve the histology of liver tissue. Therefore, research is needed to compare the potential of telbivudine and tenofovir as an option for chronic hepatitis $B$ therapy by looking at decreasing HBV DNA and aspartate transamination to platelet ratio index (APRI) scores. This analytic study uses a cross-sectional approach. Medical record data from patients on telbivudine and tenofovir therapy included APRI score parameters, namely AST levels and platelet counts, as well as HBV DNA at 0 and 12 months. APRI score data were compared using independent and dependent $t$ test with a $p$ value $<0.05$. Among 145 patients, 103 patients received telbivudine therapy, and 42 patients were treated with tenofovir. The mean decrease in APRI scores in the telbivudine group was $1.17 \pm 0.17$, while in the tenofovir group $0.75 \pm 0.42$. Significant decrease in APRI scores in both groups before and after therapy $(p=0.00)$. However, no significant difference was found in telbivudine or tenofovir group $(p=0.28)$. In conclusion, there is no significant difference in the potential for antiviral therapy between telbivudine and tenofovir in reducing the APRI score in chronic hepatitis B patients.
\end{abstract}

Keywords: APRI score, hepatitis B, telbivudine, tenofovir.

* Divisi Gastroenterohepatologi, Departemen IImu Penyakit Dalam, Fakultas Kedokteran,

Universitas Brawijaya-RSUD Dr. Saiful Anwar Malang

E-mail: bogi.pratomo@gmail.com 


\section{Pendahuluan}

Infeksi virus Hepatitis B saat ini mulai merupakan masalah kesehatan masyarakat yang besar serta serius, karena selain manifestasinya sebagai penyakit HBV akut beserta komplikasinya, lebih penting ialah dalam bentuk sebagai pengidap $\mathrm{HbsAg}$ kronik, yang dapat merupakan sumber penularan bagi lingkungan. ${ }^{1}$ Setiap tahun jumlah pengidap semakin bertambah, karena reservoir pengidap HBV yang cukup besar merupakan wadah penularan yang terusmenerus untuk sekitarnya. Saat ini di seluruh dunia diperkirakan lebih 300 juta orang pengidap HBV persisten, hampir $74 \%$ (lebih dari 220 juta) pengidap bermukim di negaranegara Asia.2,3 Di Indonesia prevalensi pengidap HBV memperlihatkan adanya variasi yang besar yaitu dari sedang sampai tinggi.3,4

Penatalaksanaan hepatitis B secara umum memiliki tujuan untuk supresi jangka panjang infeksi virus hepatitis $B$ melalui terapi, dan pencegahan transmisi dengan vaksinasi, sehingga dapat meningkatkan kualitas hidup dan kesintasan pasien yang terinfeksi. Terapi juga diberikan untuk mencegah perkembangan penyakit, progresi penyakit menjadi fibrosis lanjut hingga sirosis, sirosis dekompensata, penyakit hati lanjut, karsinoma hepatoselular, dan kematian, sekaligus mencegah terjadinya transmisi virus. 4,5

Terapi dengan analog nukleosida umumnya cukup efektif dan relatif bebas efek samping. Namun, tingginya kemungkinan resistensi adalah masalah yang harus dihadapi. Telbivudin dan tenofovir merupakan analog nukleosida untuk terapi hepatitis B dengan efektivitas tinggi dan tingkat resistensi yang rendah. ${ }^{5}$

Terapi dengan telbivudin selama 52 minggu pada pasien hepatitis $B$ kronik dengan $\mathrm{HbeAg}$ positif memberikan hasil DNA VHB tidak terdeteksi pada $60 \%$ pasien dibandingkan dengan 40,4\% pada pasien yang diberikan lamivudin. Pada studi lain juga didapatkan bahwa pemberian telbivudin selama 52 minggu lebih superior daripada adefovir dalam menekan DNA VHB sampai tidak terdeteksi $(60 \%$ vs $40 \%)$ dan serokonversi HbeAg ( $28 \%$ vs $19 \%$ ). 5,6

Kekurangan telbivudin adalah profil resistensinya yang kurang baik. Studi GLOBE menunjukkan bahwa tingkat resistensi telbivudin lebih rendah daripada lamivudin, namun resistensi genotipik pada motif YMDD masih ditemukan pada 2,3-5\% pasien pada terapi tahun pertama dan $21,6 \%$ pasien pada terapi tahun kedua. Resistensi terutama terjadi lewat mutasi titik M204I. Mengingat pola mutasinya yang sesuai, resistensi silang antara telbivudin dan lamivudin sangat mungkin terjadi.6,7,8 Namun, terapi tenofovir jangka panjang tetap berisiko timbulnya resistensi. Apabila terjadi resistensi, maka akan timbul permasalahan dalam pemilihan terapi penggantinya karena keterbatasan obat antivirus yang tersedia. 9,10

Sebuah penelitian terdahulu menyatakan bahwa efektivitas telbivudin bisa ditingkatkan dan resistensinya bisa ditekan bila terapi ini hanya diberikan pada kelompok pasien tertentu saja. Pada pasien dengan HbeAg positif, DNA VHB basal $<10^{9} \mathrm{kopi} / \mathrm{ml}$, ALT basal $>2 x$ batas atas normal, dan terdapat DNA VHB tidak terdeteksi pada minggu ke 24 terapi, makan pada akhir 2 tahun terapi bisa tercapai DNA VHB tidak terdeteksi pada $89 \%$ pasien, serokonversi $\mathrm{HbeAg}$ pada $52 \%$, dan resisitensi hanya pada $1,8 \%$ pasien. Demikian pula pada pasien dengan $\mathrm{HbeAg}$ negatif, DNA VHB basal $<10^{7} \mathrm{kopi} / \mathrm{ml}$, dan terdapat DNA VHB tidak terdeteksi pada minggu ke 24 terapi, maka pada akhir 2 tahun terapi bisa tercapai DNA VHB tidak terdeteksi pada $91 \%$ pasien dan resistensi hanya ditemukan pada 2,3\% pasien. Kelompok pasien dengan karakteristik tersebut, atau disebut super responders adalah target utama terapi telbivudin. 5,10 
Pada populasi HbeAg positif, tenofovir mampu menekan DNA VHB sampai $<400$ kopi/ml pada $76 \%$ pasien, jauh lebih unggul daripada kelompok adefovir, dengan penekanan sampai di bawah kadar tersebut hanya terjadi pada $13 \%$ pasien. Pada studi ini juga tidak ditemukan timbulnya resistensi terhadap tenofovir pada pemakaian 48 minggu. Terapi tenofovir selama 3 tahun mampu menekan HBV DNA sampai di bawah $400 \mathrm{kopi} / \mathrm{ml}$ pada $72 \%$ pasien dengan HbeAg positif, tanpa memunculkan resistensi. ${ }^{10}$

Seiring munculnya bukti keamanan dan efektivitas jangka panjang tenofovir, terapi ini telah direkomendasikan sebagai terapi lini pertama oleh beberapa panduan. Namun demikian, terapi tenofovir jangka panjang juga memiliki risiko timbulnya resistensi. Apabila telah terjadi resistensi tenofovir, timbul permasalahan dalam pemilihan terapi penggantinya karena keterbatasan obat antivirus yang tersedia serta tujuan awal pengobatan hepatitis $B$ untuk mencegah perburukan fibrosis hati menjadi tak tercapai. Sejauh ini, tenofovir memiliki profil resistensi yang cukup baik sehingga obat ini efektif digunakan pada pasien yang sudah mengalami resistensi dengan terapi lain. 9,10

Rasio antara skor aspartate aminotransferase (AST) dengan platelet ratio index (APRI) merupakan salah satu pemeriksaan noninvasif serologis untuk menilai derajat fibrosis hati yang mudah dilakukan dan telah tervalidasi. Skor APRI merupakan surrogate marker yang telah menunjukkan akurasinya dalam penilaian derajat fibrosis hati pada pasien terinfeksi virus hepatitis B sebelum memulai pengobatan dan efek pengobatan antivirus. ${ }^{11,12.13}$

Oleh karena itu, perlu dilakukan penelitian untuk membandingkan potensi telbivudin dan tenofovir sebagai pilihan terapi hepatitis B kronis. Penelitian ini melihat penurunan HBV DNA dan skor APRI untuk menilai derajat fibrosis hati sehubungan dengan pemberian terapi telbivudin dan tenofovir.

\section{Bahan dan Metode}

Penelitian menggunakan rancangan cohort retrospective dengan pengambilan sampel secara cross-sectional (potong lintang). Populasi terjangkau adalah semua pasien dengan infeksi Hepatitis $B$ yang ada di Provinsi Jawa Timur. Sampel pada penelitian ini adalah pasien rawat jalan di Poli Gastroenterohepatologi di RSUD. Dr. Saiful Anwar Malang dengan diagnosis Hepatitis B yang memulai pengobatan sejak tahun 2013. Kriteria inklusi meliputi: pasien dengan diagnosis hepatitis $B$ dengan rentang usia 1860 tahun, memulai terapi sejak tahun 2013 dengan data awal berupa HBV DNA, SGOT, SGPT, jumlah platelet, yang kemudian dilihat kembali pada bulan ke 12 sejak awal terapi. Data yang dikumpulkan berasal dari rekam medik meliputi data pengobatan pasien di poliklinik rawat jalan di RSUD. Dr. Saiful Anwar Malang mulai bulan Januari 2013 sampai dengan Desember 2017. Penelitian ini merupakan studi rekam medis tertutup. Alur penelitian ini dapat dilihat pada Gambar 1.

Rasio antara skor aspartate aminotransferase (AST) dengan platelet ratio index (APRI) merupakan salah satu pemeriksaan noninvasif serologis untuk menilai derajat fibrosis hati yang dihitung dengan rumus:

APRI= [( AST / ULN AST ) x 100] / Platelets (109/L)]

Keterangan :

AST: Kadar AST pasien (IU/L)

ULN AST: batas atas AST normal (IU/L)

Platelet: jumlah platelet pasien (10^9/L) 


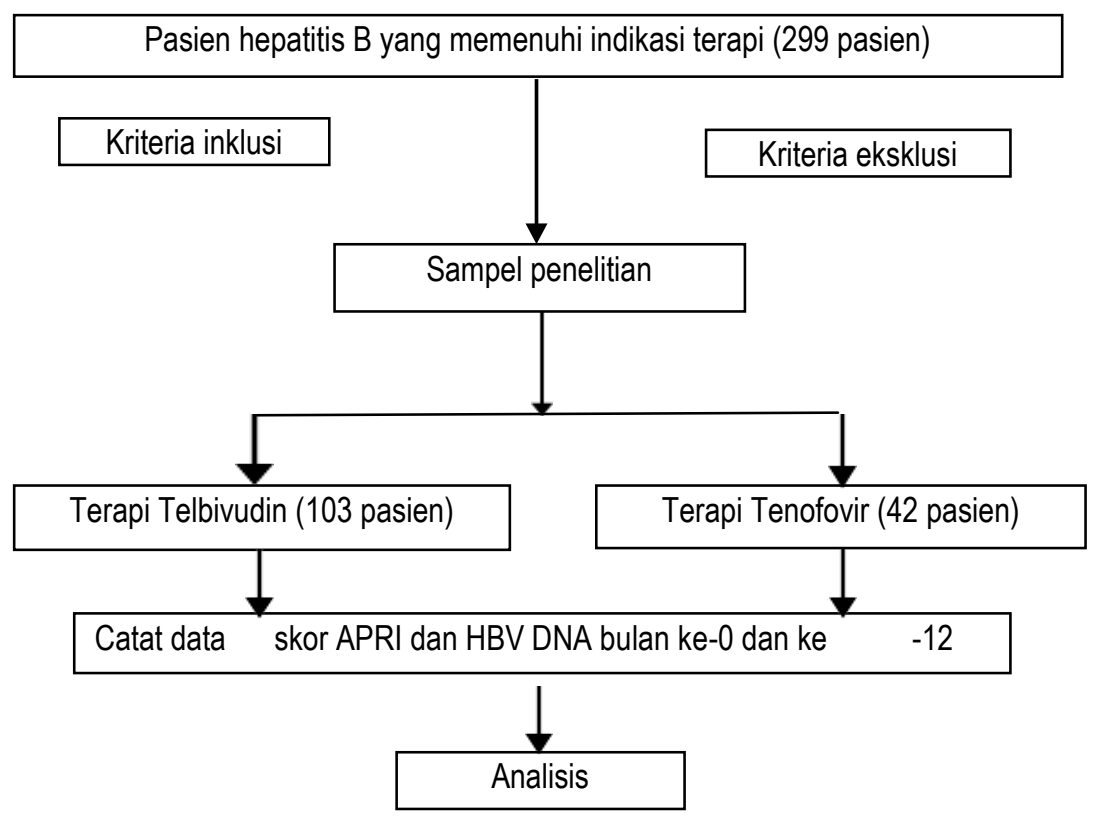

Gambar 1. Alur penelitian.

Hasil

Berdasarkan 145 data rekam medis yang memenuhi kriteria inklusi dan eksklusi, 103 (70\%) pasien mendapatkan terapi antivirus telbivudin dan 42 (30\%) pasien diterapi dengan tenofovir. Skor APRI menggunakan nilai cut off 1 untuk membedakan fibrosis signifikan $(>1)$ dan non fibrosis (<1). Skor APRI sebelum pengobatan pada kelompok telbivudin menunjukkan fibrosis signifikan (>1), sedangkan pada kelompok tenofovir terdapat dua kelompok yaitu tenofovir $A$ yang menunjukkan fibrosis signifikan (>1) dan tenofovir B untuk sebaliknya. Kelompok telbivudin menunjukkan rerata yang lebih tinggi dibandingkan dengan kelompok tenofovir, namun tidak ada perbedaan yang signifikan secara statistik (Tabel 1). Skor APRI 12 bulan setelah pengobatan pada kedua kelompok menunjukkan rerata yang lebih rendah secara signifikan daripada sebelum pengobatan seperti yang ditunjukkan pada Tabel 2.

Untuk melihat ada atau tidaknya perbaikan dari proses fibrosis hati pada kedua kelompok, peneliti melakukan uji beda penurunan skor APRI yang hasilnya ditunjukkan pada Tabel 3. Secara umum, rerata penurunan skor APRI pada kelompok telbivudin lebih besar daripada kelompok tenofovir, namun perbedaannya tidak signifikan.

Pada kelompok telbivudin, $67 \%$ pasien mengalami penurunan HBV DNA hingga mencapai kadar yang tidak terdeteksi pada bulan ke-12, dan pada kelompok tenofovir, pasien yang mencapai HBV DNA tidak terdeteksi pada bulan ke-12 sebanyak $64,2 \%$, seperti yang ditunjukan pada Tabel 4 .

Tabel 1. Uji beda skor APRI antara pasien yang diterapi dengan telbivudin dan tenofovir sebelum pengobatan.

\begin{tabular}{clcc}
\hline Skor APRI & Kelompok & Rerata & $p$-value \\
\hline \multirow{3}{*}{ Sebelum pengobatan } & Telbivudin & $1,56 \pm 0,18$ & \\
& Tenofovir A & $1,19 \pm 0,44$ & 0,382 \\
& Tenofovir B & $0,52 \pm 0,13$ & \\
\hline
\end{tabular}


Tabel 2. Uji beda skor APRI antara pasien yang diterapi dengan telbivudin dan tenofovir setelah 12 bulan pengobatan.

\begin{tabular}{clcc}
\hline Skor APRI & \multicolumn{1}{c}{ Kelompok } & Rerata & $p$-value \\
\hline \multirow{2}{*}{ Setelah 12 bulan pengobatan } & Telbivudin & $0,40 \pm 0,4$ & \multirow{2}{*}{$0,000^{*}$} \\
& Tenofovir (A dan B) & $0,52 \pm 0,13$ & 0,0 \\
\hline
\end{tabular}

Keterangan: ${ }^{*} p<0.05=$ terdapat perbedaan signifikan berdasar independent $t$-test.

Tabel 3. Uji beda penurunan skor APRI antara pasien yang diterapi dengan telbivudin dan tenofovir setelah 12 bulan pengobatan.

\begin{tabular}{cllc}
\hline Parameter & Kelompok & Rerata & $p$-value \\
\hline & Telbivudin & $1,17 \pm 0,17$ & \\
Penurunan skor APRI & Tenofovir A & $0,75 \pm 0,42$ & 0,279 \\
& Tenofovir B & $0,26 \pm 0,37$ & \\
\hline
\end{tabular}

Tabel 4. Persentase pasien dengan HBV DNA tidak terdeteksi setelah diterapi dengan telbivudin dan tenofovir selama 12 bulan pengobatan.

\begin{tabular}{ccccc}
\hline Kelompok & $\begin{array}{c}\text { Jumlah } \\
\text { pasien yang } \\
\text { diterapi }\end{array}$ & $\begin{array}{c}\text { Jumlah pasien dengan } \\
\text { HBV DNA tidak terdeteksi } \\
\text { pada bulan ke-12 }\end{array}$ & $\begin{array}{c}\text { Selisih pasien } \\
\Delta\end{array}$ & Persentase \\
\hline Telbivudin & 103 & 69 & 34 & $67,0 \%$ \\
Tenofovir & 42 & 27 & 15 & $64,2 \%$ \\
\hline
\end{tabular}

\section{Pembahasan}

APRI merupakan marker paling akurat dan sederhana untuk memprediksi fibrosis signifikan pada hepatitis B kronis. Walaupun signifikansi klinisnya dalam guideline pencegahan dan tatalaksana hepatitis $B$ dari WHO direkomendasikan dalam menilai derajat fibrosis liver, nilai prediktifnya masih perlu didemonstrasikan pada orang dewasa dengan fibrosis terkait HBV. APRI score secara signifikan lebih tinggi pada orang dewasa dengan $\mathrm{HbeAg}$ positif yang mengalami fibrosis signifikan, dibandingkan pasien dengan fibrosis ringan. APRI juga mengindikasikan perbedaan signifikan antara orang dewasa dengan inflamasi ringan dan signifikan. Hal ini menunjukkan bahwa APRI berhubungan erat dengan progresi penyakit liver, termasuk derajat fibrosis dan inflamasi. Analisis regresi linear juga mengindikasikan korelasi antara APRI dengan fibrosis/ inflamasi liver. ${ }^{12,13}$
Pada penelitian ini, analisis skor APRI dilakukan pada saat sebelum pengobatan dan 12 bulan setelah pengobatan. Skor APRI sebelum pengobatan pada kelompok telbivudin menunjukkan rerata yang lebih tinggi dibandingkan dengan kelompok tenofovir, namun tidak ada perbedaan yang signifikan secara statistik ( $p=0,382)$. Hal ini menunjukkan kondisi fibrosis hati pada kedua kelompok sebelum terapi tidak berbeda signifikan. Skor APRI 12 bulan setelah pengobatan pada kedua kelompok menunjukkan rerata yang lebih rendah secara signifikan dibandingkan dengan skor APRI sebelum pengobatan. Hal ini menunjukkan baik terapi telbivudin maupun tenofovir selama 12 bulan berpotensi menurunkan skor APRI secara signifikan $(p=0,000) \cdot{ }^{14}$

Untuk melihat ada atau tidaknya perbedaan potensi telbivudin dan tenofovir, peneliti melakukan uji beda penurunan skor APRI dan HBV DNA antara kelompok telbivudin dan tenofovir. 
Secara umum, rerata penurunan skor APRI pada kelompok telbivudin lebih besar daripada kelompok tenofovir, namun perbedaannya tidak signifikan. Hasil analisis penurunan HBV DNA pada kedua kelompok juga tidak berbeda secara signifikan ( $p=$ $0,279)$.

Adanya penurunan rerata skor APRI yang signifikan pada kedua kelompok pasien menunjukkan bahwa terapi antivirus dengan telbivudin dan tenofovir berpotensi dalam memperbaiki fibrosis hati pada pasien hepatitis B kronis. Namun demikian, perbedaan antara kedua kelompok terapi tidak signifikan, sehingga baik telbivudin maupun tenofovir memiliki potensi yang sama sebagai terapi hepatitis B kronis. ${ }^{5}$ Selain itu, di dalam penelitian ini didapatkan jumlah sampel yang tidak seimbang antara kelompok tenofovir dan telbivudin sehingga dapat mempengaruhi hasil.

Potensi telbivudin dan tenofovir juga tampak pada penurunan HBV DNA. Pada kelompok telbivudin, $67 \%$ pasien mengalami penurunan HBV DNA hingga mencapai kadar yang tidak terdeteksi pada bulan ke-12. Pada kelompok tenofovir, pasien yang mencapai HBV DNA tidak terdeteksi pada bulan ke-12 sebanyak $64,2 \%$. Hal ini sesuai dengan hasil studi GLOBE bahwa terapi dengan telbivudin selama 52 minggu pada pasien hepatitis $B$ kronik dengan $\mathrm{HbeAg}$ positif memberikan hasil DNA HBV tidak terdeteksi pada $60 \%$ pasien dibandingkan dengan $40,4 \%$ pada pasien yang diberikan lamivudin. Pada studi lain juga didapatkan bahwa pemberian telbivudin selama 52 minggu lebih superior daripada adefovir dalam menekan DNA VHB sampai tidak terdeteksi (60\% vs $40 \%$ ). 6,7

Sebuah studi terdahulu meneliti tentang efektivitas terapi 48 minggu dengan tenofovir yang dibandingkan dengan adefovir. Pada populasi HbeAg positif, tenofovir mampu menekan DNA VHB sampai $<400 \mathrm{kopi} / \mathrm{ml}$ pada $76 \%$ pasien, jauh lebih unggul daripada kelompok adefovir, yaitu penekanan sampai di bawah kadar tersebut hanya terjadi pada $13 \%$ pasien. Pada pasien dengan $\mathrm{HbeAg}$ negatif, pemberian tenofovir selama 48 minggu akan menekan DNA VHB sampai di bawah $400 \mathrm{kopi} / \mathrm{ml}$ pada $93 \%$ pasien, angka yang jauh lebih besar daripada kelompok adefovir. $^{2}$

Keterbatasan studi kami adalah jenis penelitian retrospektif sehingga reliabilitas data di luar kontrol peneliti. Proporsi sampel antar kelompok terapi hepatitis B tidak sama, sehingga mungkin dapat mempengaruhi hasil. Perlu dilakukan pencatatan berkala dan memperluas evaluasi perbandingan derajat fibrosis dengan parameter lain ataupun dengan baku emas yaitu biopsi hati.

\section{Kesimpulan}

Tidak terdapat perbedaan yang signifikan dalam potensi terapi antivirus antara telbivudin dan tenofovir dalam menurunkan skor APRI pasien hepatitis B kronis.

\section{Daftar Pustaka}

1. Razavi-Shearer D, Gamkrelidze I, Nguyen MH, Chen D-S, Van Damme P, Abbas Z, et al. Global Prevalence, Treatment, and Prevention of Hepatitis B Virus Infection in 2016: A Modelling Study. The lancet Gastroenterology \& Hepatology. 2018; 3 (6):383-403.

2. Khan HA, Baig FK, Mehboob R. Nosocomial Infections: Epidemiology, Prevention, Control and Surveillance. Asian Pacific Journal of Tropical Biomedicine. 2017; 7(5):478- 82.

3. Muljono DH. Epidemiology of hepatitis $B$ and $C$ in Republic of Indonesia. Euroasian Journal of HepatoGastroenterology. 2017; 7(1):55. 
4. Gani RA, Hasan I, Djumhana A, Setiawan PB. Konsensus Nasional Penatalaksanaan Hepatitis B. Perhimpunan Peneliti Hati Indonesia (PPHI). 2012.

5. European Association for the Study of the Liver (EASL). EASL Clinical Practice Guidelines: Management of Chronic Hepatitis B. Journal of Hepatology. 2009; 50(2):227-42.

6. Krastev Z, Petrova D, Kotzev I, Celen MK, Mendelson M, Chandra R, Pandey $P$, Hamed K. Telbivudine vs Tenofovir in Hepatitis B e Antigen-Negative Chronic Hepatitis B Patients: OPTIMA Roadmap Study. World J Hepatol. 2016; 8(32):1402 - 1413.

7. Kumar M, Satapathy $S$, Monga R, Das $\mathrm{K}$, Hissar S, Pande $\mathrm{C}$, et al. A Randomized Controlled Trial of Lamivudine to Treat Acute Hepatitis B. Hepatology. 2007; 45(1):97-101.

8. Baumert TF, Thimme R, von Weizsäcker F. Pathogenesis of Hepatitis B Virus Infection. World Journal of Gastroenterology. 2007; 13 (1):82.

9. Zhijian $Y$, Hui L, Weiming $Y$, Zhanzhou L, Zhong $C$, Jinxin $Z$, Hongyan $W$, Xiangbin D, Weizhi Y, Duoyun L, Xiaojun L, Qiwen D. Role of the Aspartate Transaminase and Platelet Ratio Index in Assessing Hepatic Fibrosis and Liver Inflammation in
Adolescent Patients with HBeAgPositive Chronic Hepatitis B. Gastroenterology Research and Practice. 2015; 1-6.

10. Terrault NA, Lok AS, McMahon BJ, Chang KM, Hwang JP, Jonas MM, et al. Update on Prevention, Diagnosis, and Treatment of Chronic Hepatitis B: AASLD 2018 Hepatitis B Guidance. Hepatology. 2018; 67(4):1560-99.

11. Rosenberg WMC, Voelker M, Thiel $R$ et al. Serum Markers Detect the Presence of Liver Fibrosis: a Cohort Study. Gastroenterology. 2004; 127:1704-13.

12. Parikh P, Ryan JD, Tsochatzis EA. Fibrosis Assessment in Patients with Chronic Hepatitis B Virus (HBV) Infection. Ann Transl Med. 2017;5 (3):40.

13. Li Q, Ren X, Lu C, Li W, Huang Y, Chen L. Evaluation of APRI and FIB-4 for Noninvasive Assessment of Significant Fibrosis and Cirrhosis in HBeAgNegative CHB Patients with $A L T>2$ ULN: A Retrospective Cohort Study. Medicine. 2017; 96:12.

14. Tenggara IR, Lesmana CRA, Gani RA. Treatment Response Monitoring of Chronic Hepatitis B Patients using Transient Elastography and Aspartate Aminotransferase-to-Platelet Ratio Index (APRI). Acta Med IndonesIndones J Intern Med. 2017; 49 (3):22022. 